\title{
Primary squamous neuroendocrine carcinoma of the skin: A case report with immunohistochemical study
}

\author{
Tadashi Terada * \\ Department of Pathology, Shizuoka City Shimizu Hospital, Shizuoka, Japan
}

Received: January 4, 2016

Accepted: August 8, 2016

Online Published: August 22, 2016

DOI: $10.5430 /$ crcp.v4n1p1

URL: http://dx.doi.org/10.5430/crcp.v4n1p1

\begin{abstract}
Primary neuroendocrine carcinoma (NEC) except for Merkel cell carcinoma has rarely been reported in the skin. Herein reported is a unique case of a primary cutaneous NEC with histological features of squamous cell carcinoma (SCC) with high cellular anaplasia; the tumor is called "squamous NEC" in this report. A 77-year-old man presented with a skin tumor measuring $0.7 \mathrm{~cm} \times 0.8 \mathrm{~cm} \times 0.7 \mathrm{~cm}$ of the right second finger. A biopsy showed invasive malignant epithelial cells with keratinization. The carcinoma cells were continuous with epidermis, and showed high cellular anaplasia. No apparent lympho-vascular permeations were seen. The pathological diagnosis was poorly differentiated SCC. Because the histological features were unusual, an immunohistochemical study was performed. The carcinoma cells were positive for cytokeratin (CK) AE1/AE3, CK34BE12, CK5/6, neuron-specific enolase (NSE) (positive percentage $(\mathrm{PP})=70 \%)$, chromogranin $(\mathrm{PP}=95 \%)$, synaptophysin $(\mathrm{PP}=95 \%)$, NCAM (PP $=20 \%)$, p63, p40, S100 protein (Langerhans cells), and Ki-67 (labeling index $(\mathrm{LI})=98 \%$ ). The carcinoma cells were negative for CK7, CK8, CK9, CK14, CK18, CK19, CK20, CK CAM5.2, smooth muscle actin, vimentin, desmin, HMB45, p53, CD45, TTF-1, HCG, and surfactant apo-protein. Because the skin SCC showed neuroendocrine features and the neuroendocrine cells exceeded 50\% of the total tumor cell population, a diagnosis of squamous NEC was made. The histological features, NEC features, high anaplasia, and high Ki-67 labeling index ( $\mathrm{LI}=98 \%)$ suggested poor prognosis. Systemic investigations using CT, MRI, PET, and upper and lower gastrointestinal endoscopy revealed no tumors except for the finger tumor. No lympho-adenopathy was seen. The outcome seemed not good. The tumor of the finger was difficult for operation. Wide excision or finger amputation is considered.
\end{abstract}

Key Words: Skin, Squamous cell carcinoma, Neuro-endocrine, Neuroendocrine carcinoma, Immunohistochemistry

\section{INTRODUCTION}

Primary neuroendocrine tumors (NET) and neuroendocrine carcinomas (NEC) are extremely rare in the skin. In the WHO blue books of skin tumors ${ }^{[1]}$ and soft tissue tumors, ${ }^{[2]}$ there are no descriptions of NET except for Merkel cell carcinoma (MCC). ${ }^{[3]}$ Thus, there are now no descriptions of primary cutaneous NET and NEC in the skin and soft tissue tumors in the WHO blue books.
In other organs such as gastrointestinal tracts and lungs, the NET and NEC show histological features of medullary neoplasms consisting of small tumor cells arranged in ribbon, cord, sinusoidal, rosette and trabecular appearances typically seen in carcinoid (NET grade 1), atypical carcinoid (NET grade 2), and NECs (NET grade 3 or NEC) such as small cell carcinoma and large cell NEC. In addition, NET has never shown SCC features, and vice versa.

\footnotetext{
*Correspondence: Tadashi Terada, MD, PhD; Email: piyo0111jp@yahoo.co.jp; Address: Department of Pathology, Shizuoka City Shimizu Hospital, Miyakami 1231 Shimizu-Ku, Shizuoka 424-8636, Japan.
} 
Primary cutaneous NET has been reported as a name of carcinoid ${ }^{[4-7]}$ there have been only 4 cases of primary cutaneous carcinoid, to the best of the author's knowledge. ${ }^{[4-7]}$ Primary cutaneous NEC has been reported as cutaneous NEC in 6 cases, ${ }^{[8-13]}$ to the best of the author's knowledge. Thus, primary cutaneous NET and NEC except for MCC are exceptionally rare. Herein reported is a very unique case of primary cutaneous squamous NEC whose hematoxylin and eosin (HE) diagnosis was squamous cell carcinoma (SCC) with high cellular anaplasia. That is, the tumor was SCC in $\mathrm{HE}$, and was NEC in immunohistochemistry. Herein, the tumor is tentatively called "squamous NEC".
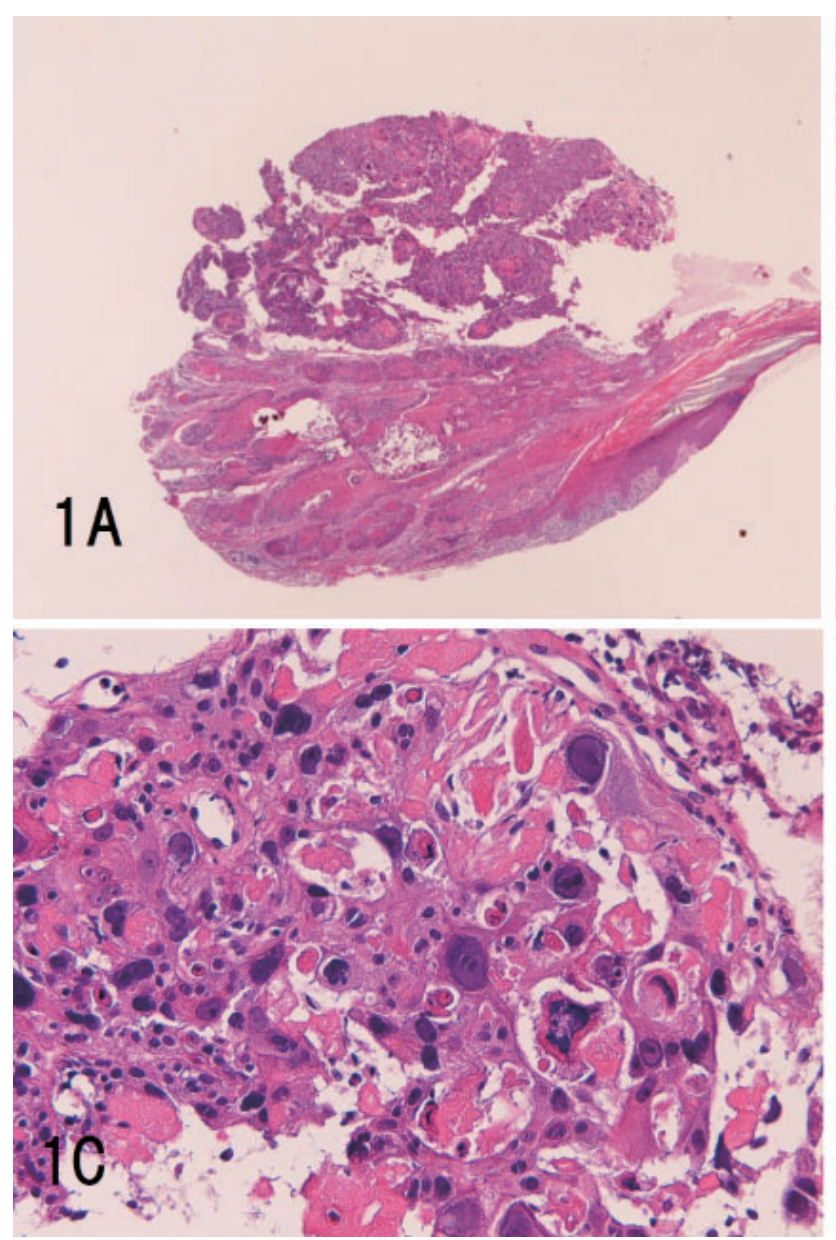

\section{CASE REPORT}

A 77-year-old man presented with a tumor measuring $0.7 \mathrm{~cm} \times 0.8 \mathrm{~cm} \times 0.7 \mathrm{~cm}$ of the right $2^{\text {nd }}$ finger. A biopsy of the tumor showed invasive malignant epithelial cells with keratinization (see Figure 1A-D). Individual keratinization, cancer pearls, and mitotic figures were scattered. Intercellular bridges were noted under high magnification. The carcinoma cells were continuous with the epidermis, and showed a high cellular anaplasia including monster-like bizarre cells. No apparent lympho-vascular permeations were seen. The pathological diagnosis was SCC with high cellular anaplasia.
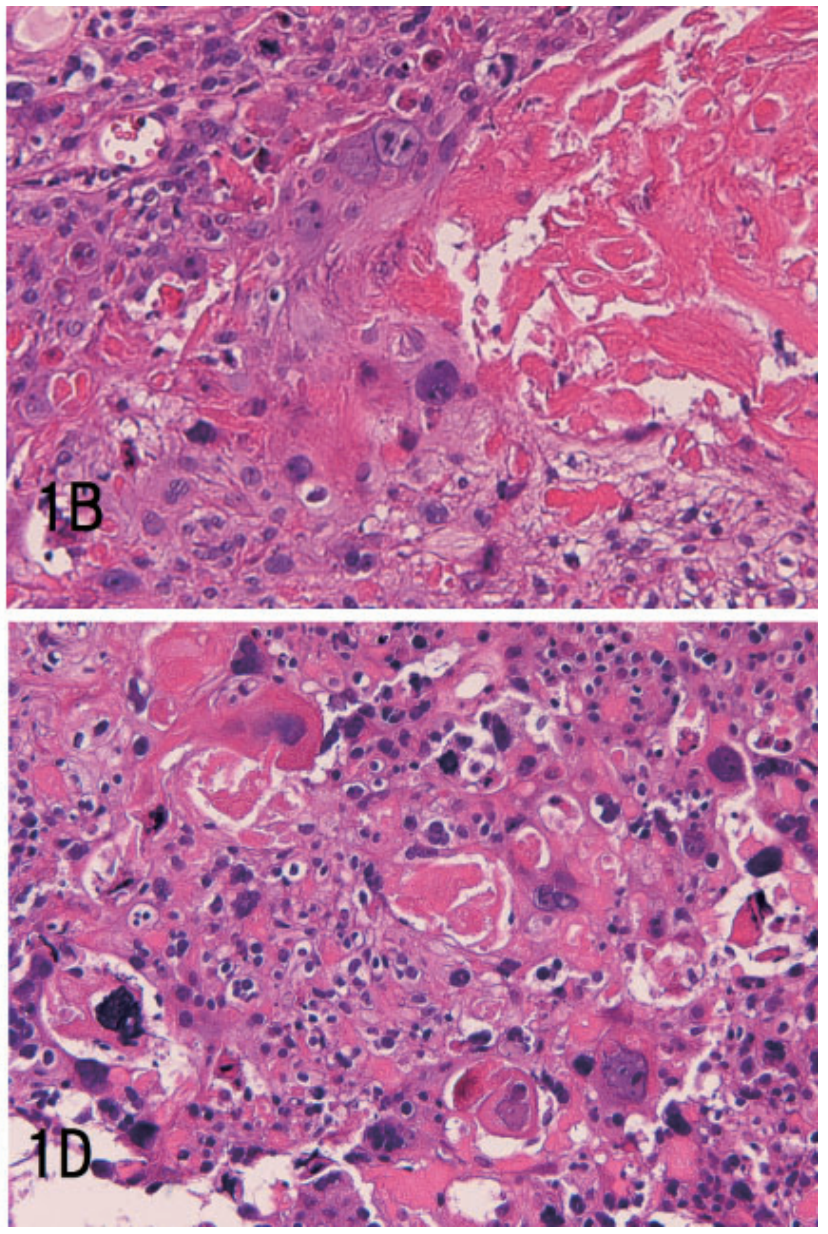

Figure 1. Morphologically of the tumor. The tumor is located in the dermis and continuous with epidermis (A). The tumor shows wide keratinization and high grade atypia regarded as squamous cell carcinoma (SCC) (A). High power views (B, C and D) shows keratinization, individual keratinization, cancer pearls, and very high grade cellular anaplasia including giant bizarre cells. All HE. A, $\times 50$. B, C, D; $\times 200$.

Since the histological features were unusual, an immunohistochemical study was performed with the use of the two-steps Dako Envision method as previously reported. ${ }^{[14-16]}$ In brief, the paraffin sections were incubated at room temperature for $5 \mathrm{~min}$ in phosphate buffered-saline (PBS) in an autoclave in order to enhance antigenicity (antigen retrieval). After washing by PBS for three times each $5 \mathrm{~min}$, the sections were treated overnight at $4^{\circ} \mathrm{C}$ by the primary antibodies, all of which were commercially obtained but were not listed herein due to space limitation. The dilutions of the first antibodies 
were 1:50-1,000; the dilutions were determined depending on the manufacturer's instruction. Next, the sections were washed by PBS several times and incubated in PBS three times, each for $5 \mathrm{~min}$. The sections were, them, incubated for 2 hours at room temperature in the secondary antibody, Dako ChemMate, which is very sensitive and specific and consists of the secondary antibody combined with dextran polymer and horseradish peroxidase. The section were then washed three time by PBS and incubated in PBS 3 times, each 5 min. The peroxidase was colored by diaminobenzidine (DAB), yielding brown reaction products. After washing several times by PBC, the sections were lightly stained with hematoxylin and eosin. Positive and negative controls were carried out internally and externally using appropriate tissues; for example in neuroendocrine antigens, colorectal carcinoids were utilized.

The carcinoma cells were positive for cytokeratin (CK) AE1/AE3 (see Figure 2A), CK 34BE12 (see Figure 2B), CK5/6 (see Figure 2C), neuron-specific enolase (NSE) (positive percentage $(\mathrm{PP})=70 \%$ ) (see Figure $2 \mathrm{D})$, chromogranin $(\mathrm{PP}=95 \%)($ see Figure $2 \mathrm{E})$, synaptophysin $(\mathrm{PP}=95 \%)$ (see Figure 2F), NCAM or CD56 (PP = 20\%) (see Figure 2G), p63 (see Figure 2H), p40 (see Figure 2I), S-100 protein (Langerhans cells), and Ki-67 (see Figure 2J) (labeling index $(\mathrm{LI})=98 \%)$. The carcinoma cells were negative for CK7, CK8, CK9, CK14, CK18, CK19, CK20, CK CAM5.2, smooth muscle actin, vimentin, desmin, HMB45, p53, CD45, TTF-1, HCG, and surfactant apoprotein. Thus, since the SCC showed neuroendocrine features and the neuroendocrine cells exceeded $50 \%$ of total tumor cell population, a diagnosis of squamous NEC was made. The control tissues showed correct positive and negative staining. The histological characteristics, NEC features, high anaplasia, and high Ki-67 labeling $(\mathrm{LI}=98 \%)$ suggested a poor prognosis. Systemic investigations using CT, MRI, PET, upper and lower endoscopy revealed no tumors except for the finger tumor. No lymphoadenopathy was seen. The outcome seemed not good. The finger was difficult for operation. Now, wide excision or finger amputation is considered.

\section{Discussion}

At the present time, SCC is defined as a carcinoma showing keratinization and/or intercellular bridges or as a carcinoma with Immunohistochemical evidence for squamous epithelia such as positive high-molecular weight CKs (CK34BE12, CK5, CK6 and CK14) and/or positive p40 or p63. ${ }^{[17]} \mathrm{NEC}$ or NET is defined as epithelial tumors showing a broad neuroendocrine differentiation which is manifested as characteristic histological features and as immunohistochemical evidence of tumor cells for neuroendocrine tissue usually including chromogranin A, synaptophysin, CD56 (NCAM) Published by Sciedu Press and NSE. ${ }^{[18,19]}$ SCC has never assumed features of NET, and vice versa in the literature.

On HE histology, the present case was poorly differentiated SCC, because the carcinoma had keratinization and intercellular bridges and was continuous with the epidermis. Individual keratinization, cancer pearls, and mitotic figures were scattered. Immunohistochemical studies of high-molecular weight CKs and p40/p63 supported SCC characters of the present case. ${ }^{[17,20,21]}$ The carcinoma cells were continuous with epidermis, and showed high cellular anaplasia including monster-like bizarre cells. No apparent lympho-vascular permeation was seen. The histology was poorly differentiated SCC, but the carcinoma was different from cutaneous primary ordinary SCC with regards to its high cellular anaplasia including monster cells.

Therefore, the author performed an immunohistochemical study. The negative HCG excluded choriocarcinoma. The negative TTF-1 and surfactant apoprotein excluded a metastasis from lung adenocarcinoma. Negative reactions of carcinoma cells for smooth muscle actin, vimentin, desmin, HMB45, and CD45 excluded mesenchymal sarcomas, melanomas, and malignant lymphomas. The positive CK AE1/3, CD34BE12, CK5/6, and CK 7 indicated that the carcinoma is epithelial malignant neoplasms containing high-molecular weight CKs. The positive expressions of p63 and p40 highly suggest that the carcinoma is SCC. ${ }^{[17,20,21]}$ Negative p53 suggested no mutations of the p53 gene. ${ }^{[22]}$ The high Ki-67 LI (98\%) suggests that the carcinoma has a very high cell proliferative activity ${ }^{[23,24]}$ and the prognosis is not good. The positive S100 implies that the Langerhans cells (antigen presenting cells) are present in the carcinoma.

Surprisingly, the SCC in the present case immunohistochemically showed broad neuroendocrine features, ${ }^{[18,19]}$ and were positive for NSE (positive percentage $(\mathrm{PP})=70 \%$ ), chromogranin $(\mathrm{PP}=95 \%)$, synaptophysin $(\mathrm{PP}=95 \%)$, and NCAM (CD56) $(\mathrm{PP}=20 \%)$. The author hesitated in making the pathological diagnosis. The tumor is certainly primary cutaneous tumor without metastasis because no tumors were found in the body. It was not determined whether the carcinoma should be termed SCC or NET. However, the author diagnosed the lesion as primary cutaneous squamous NEC.

The present case is very similar to the cases of Hosaka et al., ${ }^{[10]}$ Dadzie et al., ${ }^{[12]}$ and Isimbaldi et al.. ${ }^{[8]}$ Their cases also showed squamoid features on HE sections; however, immunohistochemical and electron microscopic investigations of their cases showed neuroendocrine features. They diagnosed the lesion as primary cutaneous NEC, rather than SCC. These diagnosis and diagnostic dilemma are similar to those of the present case. 


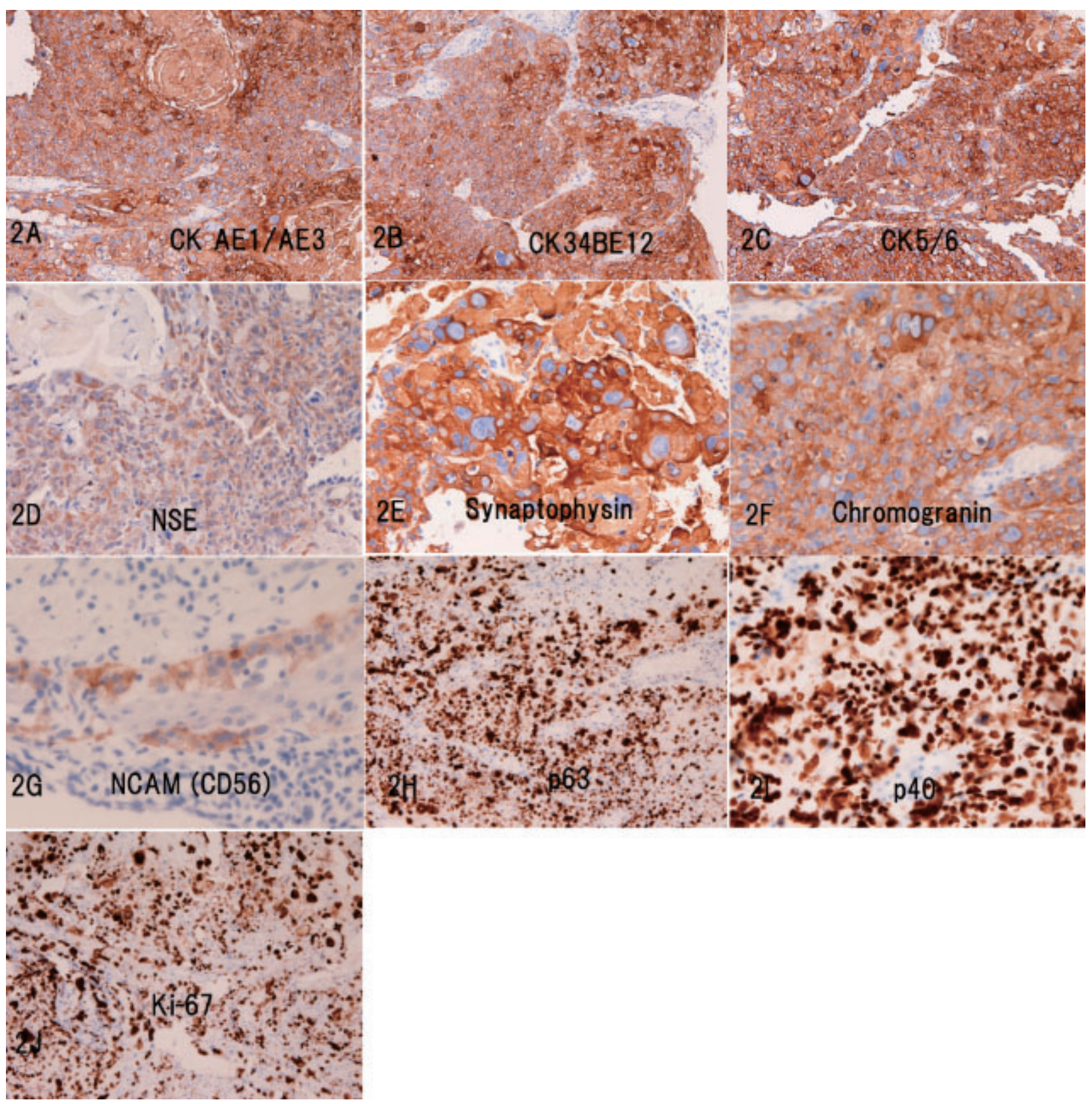

Figure 2. Immunohistochemical findings. The carcinoma cells were positive for cytokeratin (CK) AE1/AE3 (A), CK34BE12 (B), CK5/6 (C), neuron-specific enolase (D), chromogranin (E), synaptophysin (F), NCAM (G), p63 (H), p40 $(\mathrm{I})$, and Ki-67 (J) (labeling index $=98 \%$ ). Immunostaining. A-H, J: $\times 200$. I: $\times 250$

The present case is not an MCC, which shows monotonous small cell carcinoma-like cells proliferation. MCC is characterized monotonous proliferation of relatively small cells with hyperchromatic nuclei and positivity of CK20 with a dotted immunoreaction. In MCC, CK20 is consistently positive and its perinuclear dotted immunoreactivity is a very sensitive and specific finding. These features of MCC are entirely different from those of the present case, in which the histology is SCC with keratinization and CD20 was negative. It is reported that, in some case of MCC, MCC exhibits unusual histological features. Li et al. ${ }^{[25]}$ reported a case of primary cutaneous neuroendocrine cell carcinoma with prominent microcystic features. It mimicked an eccrine carcinoma. Sirikanjanapong et al. ${ }^{[26]}$ reported a case of intraepidermal and dermal MCC with squamous cell carcinoma in situ. Hwang et al. ${ }^{[27]}$ reported a case of MCC with squamous and sarcomatous differentiations. Jones et al. ${ }^{[28]}$ reported a case showing a development of cutaneous NEC mixed with squamous cell carcinoma in erythema. Cerroni and Kerl ${ }^{[29]}$ reported a case of primary cutaneous NEC in association 
with squamous- and basal-cell carcinoma. These reported unusual variants of MCC show that the main tumor is MCC which was associated with squamoid, microcystic, carcinoma in situ, basal cell carcinoma, SCC, and sarcomatous features in the small parts of the MCC. The present case is not such a variant of MCC, because the present tumor showed no definite areas of MCC. The CK20 was negative in all tumor cells in this case.

Every tumor (particularly carcinoma) of every organ can show "neuroendocrine differentiation". ${ }^{[30,31]}$ Thus, it is frequently difficult or impossible whether carcinomas with neuroendocrine features should be labeled as "NEC" or "carcinomas with neuroendocrine differentiation". At the present time, there is no consensus of this distinction. In NEC of lungs, small cell lung carcinoma (SCLC) was defined by only HE histology, and SCLC does not express neuroendocrine features in about $10 \%$ of cases. ${ }^{[30]}$ In large cell neuroendocrine carcinoma (LCNEC) of the lung, it is mandatory to demonstrate the neuroendocrine features, but the percentage of LENEC cells with neuroendocrine features is not described in the WHO blue book of lung. ${ }^{[31]}$ However, in WHO blue book of breast, ${ }^{[32]}$ NEC is defined as a NEC whose neuroendocrine features are seen in more than $50 \%$ of the tumor cells. If this cut-off point (50\%) of the immunostainings of neuroendocrine antigens were adopted, the present case could be categorized as NEC or NET not tumors with neuroendocrine differentiation.

Therefore, there seem to be an unwritten consensus that carcinomas with neuroendocrine cells $>50 \%$ of tumor cells are called "NEC". In contrast, carcinomas with neuroendocrine cells $<50 \%$ of tumor cells are regarded as "carcinomas with neuroendocrine differentiation". In the present case, the author examined four pan-neuroendocrine markers (chromogranin, synaptophysin, NCAM, and NSE), and found that the proportion of neuroendocrine positive cells was $95 \%$ in chromogranin and synaptophysin immunostainings, $70 \%$ in NSE immunostaining, 20\% in NCAM immunostaining. It is well recognized that of the four antigens, chromogranin and synap- tophysin are the most sensitive and most specific antigens present in neuroendocrine cells. Therefore, in the present case, the neuroendocrine cells as determined by chromogranin and synaptophysin immunostainings exceeded 50\% of total tumor cells population. Thus, the present case fulfills the criteria of NEC.

The present cutaneous tumor appears primary skin tumor, because imaging techniques revealed no other tumors in the body. Immunohistochemically, the negative TTF-1 and surfactant apoprotein suggests that the tumor is not a metastasis from lung carcinoma. The CK7-/CK20- pattern is compatible with primary cutaneous tumor.

Characteristically, the present tumor showed that the tumor had high-molecular weight CKs such as CK34BE12 and CK5/6, and did not have low molecular-weight CKs such as CK CAM5.2, CK7, CK8, CK18, CK19, and CK20. CK AE1/AE3 showed moderate reaction. These findings suggest that the present tumor is carcinoma and the present tumor have only high molecular weight CKs. ${ }^{[33-35]} \mathrm{P} 63$ and p40 label many cell types including SCC cells. Although the author recently demonstrated that cutaneous basal cell carcinoma (BCC) frequently express neuroendocrine antigens, KIT and PDGFRA, ${ }^{[33]}$ the present case is not BCC histologically and immunohistochemically.

\section{Conclusions}

The author reported an extraordinary rare case of primary cutaneous SCC which showed distinct immunohistochemical features of NET. The SCC features were characterized by keratinization, intercellular bridges, and immune-expressions of high-molecular weight CKs (CK34BE12 and CK5/6) and p40/p63. The NEC features were not seen histologically, but Immunohistochemical study showed diffuse staining of chromogranin, synaptophysin, CD56 and NSE. The lesion was tentatively called squamous NEC of the skin.

\section{CONFliCtS OF INTEREST Disclosure}

The author declares no conflicts of interest.

\section{REFERENCES}

[1] World Health Organization Classification of Tumours. Pathology and genetics of skin tumours. LeBoit PE, Burg G, Weedon D, Sarasin A eds. Lyon: IARC Press; 2006.

[2] World Health Organization Classification of Tumours. Pathology and genetics of tumours of soft tissue and bone. Fletcher CDM, Unni KK, Mertens F eds. Lyon: IARC Press; 2002.

[3] Kohler S, Keri H. Merkel cell carcinoma. In: LeBoit PE, Burg G, Weedon D, Sarasin A eds. World Health Organization Classification of Tumours. Pathology and genetics of skin tumours. Lyon: IARC Press; 2006. 272p.

[4] Cokonis CD, Green JJ, Manders SM. Primary carcinoid tumor of the skin. J Am Acad Dermatol. 2004; 51: S146-8. PMid: 15577755. http://dx.doi.org/10.1016/j.jaad.2004.03.043

[5] MacKenzie DN, McCormick CS, Morris RJ. Lymph node metastasis from a primary skin carcinoid tumour. Br J Plast Surg. 2003; 56: 718 21. http://dx.doi .org/10.1016/S0007-1226(03) 00210-8

[6] Courville P, Joly P, Thomine E, et al. Primary cutaneous carcinoid 
tumour. Histopathology. 2000; 36: 566-7. PMid: 10849101. http: //dx.doi.org/10.1046/j.1365-2559.2000.00918-2.x

[7] Dijk CV, Ten Seldam RE. A possible primary cutaneous carcinoid. Cancer. 1975; 36: 1016-20. http: //dx.doi.org/10.1002/1097-0142(197509) 36:3<1016: : AID-CNCR2820360326>3.0.CO;2-L

[8] Isimbaldi G, Sironi M, Taccagni G, et al. Tripartite differentiation (squamous, glandular, and melanocytic) of a primary cutaneous neuroendocrine carcinoma. An immunocytochemical and ultrastructural study. Am J Dermatopathol. 1993; 15: 260-4. PMid: 8517496. http://dx.doi.org/10.1097/00000372-199306000-00012

[9] Gillham SL, Morrison RG, Hurt MA. Epidermotropic neuroendocrine carcinoma. Immunohistochemical differentiation from simulators, including malignant melanoma. J Cutan Pathol. 1991; 18: 120-7. PMid: 1649847. http://dx.doi.org/10.1111/j.1600-0560. 1991.tb00139.x

[10] Hosaka N, Uesaka K, Takaki T, et al. Poorly differentiated squamous cell carcinoma of the nipple: a unique case for marked exophytic growth, but little invasion with neuroendocrine differentiation. Med Mol Morphol. 2011; 44: 174-8. PMid: 21922390. http://dx.doi.org/10.1007/s00795-010-0520-5

[11] Battistella M, Durand L, Jouary T, et al. Primary cutaneous neuroendocrine carcinoma within a cystic trichoblastoma: a nonfortuitous association? Am J Dermatopathol. 2011; 33: 383-7. PMid: 21048490 http://dx.doi.org/10.1097/DAD.0b013e3181e3ceb9

[12] Dadzie O, Teixeira F. What can primary cutaneous neuroendocrine carcinomas with squamoid and neuroendocrine differentiation teach us about the origin of Merkel cells? Int J Dermatol. 2009; 48: 91-3. PMid: 19126060. http://dx.doi.org/10.1111/j.1365-4632. 2009.03840.x

[13] Bastian BC, Kreipe HH, Bröcker EB. Primary neuroendocrine carcinoma of the skin with an unusual follicular lymphocytic infiltrate of the dermis. Am J Dermatopathol. 1996; 18: 625-8. PMid: 8989938. http://dx.doi.org/10.1097/00000372-199612000-00014

[14] Terada T, Kawaguchi M, Furukawa K, et al. Minute mixed ductalendocrine carcinoma of the pancreas with predominant intraductal growth. Pathol Int. 2002; 52: 740-6. PMid: 12685552. http: //dx.doi.org/10.1046/j.1440-1827.2002.01416.x

[15] Terada T, Kawaguchi M. Primary clear cell adenocarcinoma of the peritoneum. Tohoku J Exp Med. 2005; 271: 271-5. http: //dx.doi.org/10.1620/tjem.206.271

[16] Terada T. Immunohistochemical profile of normal mesothelium and histiocytic/methothelial hyperplasia: a case report. Int J Clin Exp Pathol. 2011; 4: 631-6. PMid: 21904639.

[17] Gailey MP, Bellizzi AM, Jensen CS. Differentiating small cell carcinoma from squamous cell carcinoma in cytologic Specimens: A head-to-head comparison of p 40 and p63 using cell block immunocytochemistry. Appl Immunohistochem Mol Morphol. 2016; 24: 11-5. PMid: 25906121. http://dx.doi.org/10.1097/PAI. 0000000 000000177

[18] Terada T. Malignant glomus tumor of the foot with obvious neuroendocrine differentiation: a case report with immunohistochemical studies. Pol J Pathol. 2014; 65: 241-7. PMid: 25372423. http://dx.doi.org/10.5114/pjp. 2014.45789

[19] Terada T. Primary small cell carcinoma of prostate without immunoreactive neuroendocrine proteins but with expressions of KIT and platelet-derived growth factor- $\alpha$. Int J Urol. 2015; 22: 122-4. PMid: 25195713. http://dx.doi.org/10.1111/iju. 12616

[20] Terada T. Verrucous carcinoma of the oral cavity: a histopathologic study of 10 Japanese cases. J Maxillofac Oral Surg. 2011; 10: 14851. PMid: 22654367. http://dx.doi .org/10.1007/s12663-0 $11-0197-\mathrm{x}$
[21] Terada T. Primary pure squamous cell carcinoma of the duodenum: report of three cases. Endoscopy. 2009; 41 Suppl 2: E329-30. PMid: 19921616. http://dx.doi.org/10.1055/s-0029-1214940

[22] Terada T, Shimizu K, Izumi R, et al. Methods in pathology. p53 expression in formalin-fixed, paraffin-embedded archival specimens of intrahepatic cholangiocarcinoma: retrieval of p53 antigenicity by microwave oven heating of tissue sections. Mod Pathol. 1994; 7 : 249-52. PMid: 8008749.

[23] Terada T. Development of extrahepatic bile duct excluding gall bladder in human fetuses: histological, histochemical, and immunohistochemical analysis. Microsc Res Tech. 2014; 77: 832-40. PMid: 25091784. http://dx.doi.org/10.1002/jemt. 22406

[24] Terada T. Huge clusters of embryonic stem cells in human embryos: a morphologic study. Microsc Res Tech. 2014; 77: 825-31. PMid: 25091607. http://dx.doi.org/10.1002/jemt. 22405

[25] Li N, Wolgamot G, Argenyi Z. Primary cutaneous neuroendocrine cell carcinoma (Merkel cell carcinoma) with prominent microcystic features, mimicking eccrine carcinoma. J Cutan Pathol. 2007; 34 410-4. PMid: 17448197. http://dx.doi.org/10.1111/j.160 $0-0560.2006 .00633 . x$

[26] Sirikanjanapong S, Melamed J, Patel RR. Intraepidermal and dermal Merkel cell carcinoma with squamous cell carcinoma in situ: a case report with review of literature. J Cutan Pathol. 2010; 37: 881-5. PMid: 19702685. http://dx.doi.org/10.1111/j.1600-0560. 2009.01407. $\mathrm{x}$

[27] Hwang JH, Alanen K, Dabbs KD, et al. Merkel cell carcinoma with squamous and sarcomatous differentiation. J Cutan Pathol. 2008; 35 : 955-9. PMid: 18494821. http://dx.doi.org/10.1111/j.160 $0-0560.2007 .00917 . x$

[28] Jones CS, Tyring SK, Lee PC, et al. Development of neuroendocrine (Merkel cell) carcinoma mixed with squamous cell carcinoma in erythema ab igne. Arch Dermatol. 1988; 124: 110-3. PMid: 3337533. http://dx.doi.org/10.1001/archderm.1988.016 70010074024

[29] Cerroni L, Kerl H. Primary cutaneous neuroendocrine (Merkel cell) carcinoma in association with squamous- and basal-cell carcinoma. Am J Dermatopathol. 1997; 19: 610-3. PMid: 9415620. http://dx.doi.org/10.1097/00000372-199712000-00011

[30] Travis W, Petersen I, Nicholson S. Small cell carcinoma. In: Travis WD, Brambilla E, Muller-Hermelink K, Harris CC eds. World Health Orgnization of Tumours. Pathology and genetic of tumors of the lung, pleura, thymus and heart. Lyon: IARC Press; 2004. 31p.

[31] Brambilla E, Lantuejoul S, Pugatch B. Large cell carcinoma. In: Travis WD, Brambilla E, Muller-Hermelink K, Harris CC eds. World Health Orgnization of Tumours. Pathology and genetic of tumors of the lung, pleura, thymus and heart. Lyon: IARC Press; 2004. 45p.

[32] Ellis IO, Corneilisse CJ, Schnitt SJ, et al. Invasive breast carcinoma. In: Tavassoli FA and Delvilee P eds: World Health Orgnization of Tumours. Pathology and genetic of tumors of the breast and female genital organs. Lyon: IARC Press; 2003. 13p. PMid: 14634807.

[33] Terada T. Expression of NCAM (CD56), chromogranin A, synaptophysin, c-KIT (CD117) and PDGFRA in normal non-neoplastic skin and basal cell carcinoma: an immunohistochemical study of 66 consecutive cases. Med Oncol. 2013; 30: 444. PMid: 23292839. http://dx.doi.org/10.1007/s12032-012-0444-0

[34] Terada T, Maruo H. Simultaneous large cell neuroendocrine carcinoma and adenocarcinoma of the stomach. World $\mathrm{J}$ Gastroenterol. 2011; 17: 4831-4. PMid: 22147986. http://dx.doi.org/10.37 48/wjg.v17.i43. 4831

[35] Terada T. Small cell neuroendocrine carcinoma of the prostate: incidence and a report of four cases with an examination of KIT and PDGFRA. Prostate. 2012; 72: 1150-6. PMid: 22127977. http: $/ / \mathrm{dx}$.doi.org/10.1002/pros.22464 